\title{
The Bible of the poor in the context of poverty, COVID-19 and vaccine nationalism: Hermeneutics of liberation from the perspective of the poor
}

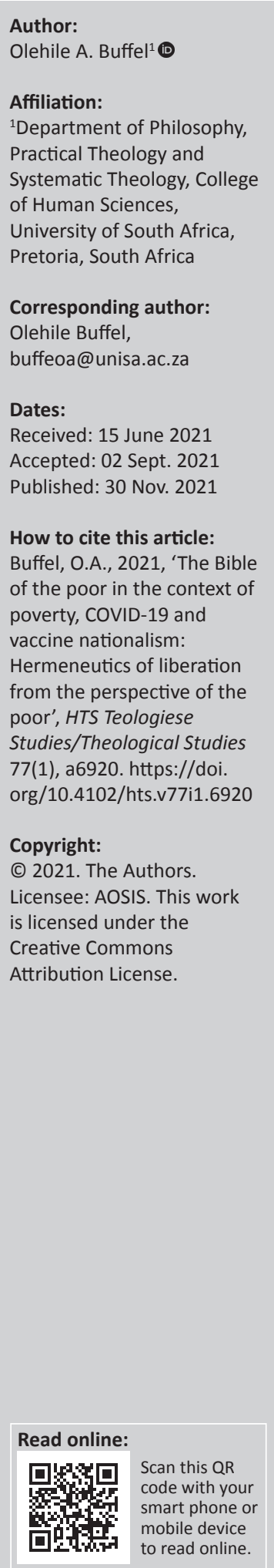

To the poor, the Bible is a particularly important book which is read and reflected upon in the context of their struggles and their lived experiences. To the critics of Black theology, it may look like 'liberation theologies' have nothing to do with the Bible and faith. On the contrary, the Bible is very central to the spiritual journey of the poor in the light of their struggles in the context of poverty and COVID-19. This is the case as the poor struggle against poverty, which is exacerbated by COVID-19 and as they are then pushed aside in the struggle to access vaccinations amidst vaccine nationalism. The poor draw inspiration from the Bible and its themes that focus on God, Jesus, the poor and oppressed, the sick, the marginalised and all people who are suffering. To the poor, God is a caring person who is the parent and advocate of the poor, the oppressed and all the people who are suffering. The poor rely on the hermeneutics of liberation as they make sense of their horrendous conditions and their lived experiences amidst poverty and COVID-19 and as they are denied access to resources that are monopolised by the rich and the powerful nations. Using a theological-liberative hermeneutics, the article argues that the Bible is central in the struggles and lived experiences of the poor in the context of poverty and COVID-19.

Contribution: The article contributes to academic discourse that perpetuates misconceptions regarding liberation theologies. An erroneous impression is created that the Bible is not important to the poor in their spiritual journeys. The article contributes to discourse about the centrality of the Bible in the context of their pain and suffering. This is the context in which poverty is exacerbated by COVID-19 and vaccine nationalism as poor countries and communities struggle to access vaccines.

Keywords: the poor; the oppressed; context; black theology; liberation theology; Bible; liberative hermeneutics; COVID-19.

\section{Introduction}

The poor continue to have the Bible as a central document in their spiritual journey. They continue to read, reread, interpret and reinterpret the Bible in the context of their pain and suffering as a result of the harsh living conditions under which they struggle to survive and live. They read the Bible contextually and have been doing that even before the social movements that popularised general and contextual reading of the Bible as championed by organisations such as Ujamah Centre attached to the University of Kwazulu-Natal and Institute for Contextual Theology (cf. Dladla 1996; West 2015:235). The marginalised poor people who are subjected to injustices regularly read the Bible. They read the Bible contextually as they attempt to make sense of their living conditions. It is in that context of pain and suffering where liberation theology is done as the poor live and survive in poverty. The grave conditions of the poor have been exacerbated by the COVID-19 pandemic which has triggered an economic crisis in the world thereby increasing poverty, inequality and unemployment. The article argues that despite the popular belief on the part of the critics about liberation theologies, the Bible continues to remain as an important document for the poor, the oppressed and the marginalised as they continue to read, re-read and reinterpret it in the light of their lived experiences and realities. There are critics of Black Theology of liberation who are members and theologians of the Afrikaans speaking churches such as Boshoff, Smith and Crafford (1971), some members of the Pentecostal churches and others who legitimised the apartheid ideology (cf. Boshoff et al. 1971; Farisani 2004:207). Farisani (2014) correctly points out that 'the Bible was used both as a tool to legitimise the apartheid ideology and as a site of struggle against it' (p. 207). The article focuses on those who used the Bible, consciously

Note: Special Collection: Reception of Biblical Discourse in Africa, sub-edited by Itumeleng Mothoagae (University of South Africa). 
and unconsciously, as a site of struggle in the efforts to make contributions to the liberation struggles of the poor.

The Bible, together with the black church remain what Mosala refers to as 'the terrain as well as the weapon of struggle for the liberation of the poor and exploited' (Mosala 1989:x). About the black church in which the Bible is read using contextual reading, Mosala (1989:xi) calls it 'that refuge to which people escape from brutalities of racism and capitalist exploitation, and which also serves as a resistance base'. The consequence of that racism and capitalist exploitation was the ongoing impoverishment of blacks. ${ }^{1}$

As the poor reflect theologically on the Bible in their various contexts characterised by poverty and the associated socioeconomic and political ills, they do so from a liberativehermeneutics, even though they may not refer to their contextual reading as such. The poor in the South African context live in informal settlements, townships and rural areas. The author grew up in an impoverished community of Bochabela in Bloemfontein where most of the elderly people with limited or no formal education, only had the Bible to read, thanks to the efforts of missionaries who ensured that they could read at least the Bible and catechism in their own languages. Linda Chisholm correctly argues 'that schools were principally aimed at ensuring baptism. As such religious instruction in Lutheran catechism was considered much more important than reading, writing and arithmetic'. (Chisholm 2017:xxv). Although that educational process ended only with the confirmation ceremony and was in pursuance of colonialism, it ensured that new converts were able to read, at least the Bible and the Lutheran catechism, in the case of Lutherans from both the Berlin Mission Society and the Hermannsburg Mission Society (cf. Chisholm 2017:xxv). In Dingaan Street, Bochabela, there were Christian parents of all denominations who read the Bible and encouraged their children to read the Bible too. The few who could not read requested their children to read for them. They also encouraged the children of their neighbours to read the Bible. The parents, including the author's parents, insisted that children should go to church where there were readings of the Bible that legitimised apartheid. At the same time, there were contextual readings of the Bible that found resonance with what later came to be referred to as contextual Bible reading. The author has also worked as a minister of the Lutheran church in all contexts where the poor are found in areas such as Kagiso, Krugersdorp, Alexandra and Mamelodi West in Gauteng province. The author also worked in rural villages such as Pella (North West province) and Ramotswa and Gaborone in Botswana. In those communities, like in all black communities the two readings of the Bible existed side by side, namely the readings that were not critical and not contextual, as well as the readings that were critical and contextual. Many of the 'young people who engaged the regime in the streets of Soweto, Sebokeng, Mamelodi, Langa, Crossroads, Uitehage and many in other townships

1.Blacks in this article refers to Africans, coloureds and Indians, that is, those who were discriminated against and referred to as non-white. This in line with the Black Consciousness understanding of blacks. throughout the country and in some rural areas' were acknowledged by Rev. Frank Chikane in his address to the participants at the 10th anniversary (1995) of the Kairos document (Chikane 1996:21). In a country that had about $80 \%$ of its citizens as Christians, many of the young people who were engaged in the struggle for liberation were from Christian families and Bible-reading families and communities (cf. Rule \& Mcwango 2010:185).

It is particularly in Alexandra where the author was struck by the levels of commitment to the critical reading of the Bible, which in the opinion of the author was contextual. What is also striking is the depth and extent of poverty in the area. This poverty exists side by side with affluence across the major highway in Johannesburg (M 2) which separates Alexandra from the affluent Sandton and its suburbs. This is what Nyapokoto refers to as 'the uneasy co-existence of poverty and opulence' as he focusses his research and analysis on the Alexandra township and Sandton, which are symbols of poverty and privilege (Nyapokoto 2014).

In the congregation and in the broader community of Alexandra, there are many people who are poor, and many are part of Bible-reading communities both in their churches and their homes. The author had organic relationships with the poor and accompanied them in their spiritual journeys as Bible-reading communities. The Lutheran church and many mission-established congregations have many people who had access to higher education and many who had no access to education above certain elementary levels. It was a common practice for missionaries to teach indigenous communities to read the Bible and the catechism and it is an ongoing common practice to read the Bible even among people who are poor and not in possession of certificates of education from high schools and universities. Many of the Christians in Alexandra in the Lutheran Church and in other denominations have a long history of participating in popular forms and contextual forms of reading the Bible that resonates with what is the contextual reading of the Bible that is championed by Ujamaa (West 2015:235).

Despite South Africa being a country that has been politically liberated from the apartheid regime, blacks remain the majority of those who are poor. In fact, statistics indicate that since 1994 poverty, inequality and unemployment have been getting worse in South Africa. In support of this reality regarding poverty, which is exacerbated by the everincreasing unemployment rate, Jonas (2019:17) argued that 'South Africa has the highest unemployment rate in the world among middle-income countries. This directly feeds our other two major crisis: poverty and inequality'. As a result of the ever-rising inequality and unemployment, poverty is getting worse, with more than half of the population being impoverished (cf. Bundy 2014:48). According to the World Bank, approximately 55.5\% of the total population live in poverty in South Africa, one of the most unequal countries in the world (World Bank 2020). 
It is therefore inevitable that impoverished black communities will read and reflect theologically as blacks. Furthermore, black theology of liberation will remain a necessity, even in the context of the existence of a rainbow nation. As black theological reflections continue, blacks do theology from a liberative-hermeneutical perspective. This is the case even though they may not refer to this as such and even though they may not be as systematic and methodical as Ujamma Centre and the Institute for Contextual Theology. They do this in the context of poverty, which is made worse by COVID-19 and its consequences. This is in spite of the fact that the critics of Black Theology would like us to believe that Black Theology and all other brands of Liberation theology have nothing to do with the Bible. It is the churches of blacks that remain vibrant and that continue to grow, while they read and reread the Bible both in churches and outside churches. In their spiritual journeys, black Christians regularly read the Bible in their journeys of faith. They identify with and get inspiration from the biblical themes that focus on God and his role in the Exodus experience, the Babylonian captivity experience, Jesus, the poor, the sick, the marginalised in the Bible stories, and all the people who are suffering. The liberative-hermeneutical perspective makes the poor appreciate God as a liberating God and God of justice who cares for the poor, the oppressed and all the people who are suffering. Like the Hebrews of old, the poor appreciate and understand God as a God who sees their suffering, who listens to their cry and who comes down to liberate them (Exodus story). As they do that, it is in the context of their impoverishment and their struggles to access vaccinations amidst vaccine nationalism of rich nations, so that they, like the rich, can save and sustain their lives and livelihoods.

\section{What is liberation theology?}

For us to appreciate the liberative-hermeneutical experience that is at play in the spiritual journey of the poor and oppressed, there is a need to understand what liberation theology is and what it is not. Liberation theology is a theology of the people, which according to Gibellini (1987) 'arose out of an ethical indignation at the poverty and the marginalization of the great masses of the poor and oppressed' (4). That it is a people's theology means that it is written from the perspective of the poor, that is, 'from the underside of history' (Gibellini 1987:4). Liberation theology as a theology of the people is also a by-product of the ongoing struggle of the poor to overcome poverty and oppression. It is not a theology of the experts crafted in quiet libraries and then offered to 'the masses' (Gutierrez 1983:iv). It is not a theology done from ivory towers. It is a theology of the people arising in a context where theologians are merely 'note-takers' who are in solidarity with the people and who are struggling alongside the poor and the oppressed. Theologians are what liberation theologians refer to as 'organic intellectuals' who go to the poor and work with and alongside the poor, in a non-paternalistic way, as together they articulate the theology of the people (cf. Berryman 1987:36). It is the people's theology in contrast to a textbook theology (cf. Gutierrez 1983:vii). The theologians put together the reflections of the people, and they capture their thinking and their acting. They also provide support out of scripture (the Bible) and the tradition of the church (cf. Gutierrez 1983:iv). They are able to do this provided they remain the organic intellectuals who continue to have organic relationships with the masses who are the poor and the oppressed (Buffel 2010). In the South African context, community leaders, pastors and theologians who facilitated the process that led to the Kairos document in 1995 were part of the communities that were involved in the struggle for liberation (Dladla 1996; Kairos Southern Africa 2011).

According to Gutierrez (1983), 'liberation theology is a critical reflection on praxis in the light of the word of God' (p. vii). Expressed slightly with a different emphasis, Gutierrez defines liberation theology as 'a critical reflection from the historical praxis in the light of faith' (Gutierrez cited by Gibellini 1987:4; cf. Gutierrez 1999:27). A somewhat extended definition is provided by Gutierrez (1988) who states that liberation theology is a theological reflection born of the experience of shared efforts to abolish the current unjust situation and to build a different society' (p. xiii). With regard to Black Theology of Liberation, which emerges within the context of liberation theology, Boesak provides the following definition: 'a theological reflection of black Christians on the situation in which they live and on their struggle for liberation' (Boesak 1977:1). Boesak reiterates questions that blacks are raising such as the following: What does it mean to believe in Jesus Christ when one is black and living in a world controlled by white racists? And what if these racists call themselves Christians also? It does not mean that now that political liberation has been attained in the South African context in the context of Dr Nelson Mandela's noble pursuit of reconciliation and nation-building, blacks must now stop raising questions arising out of their context of worsening poverty, inequality and unemployment. They have no choice but to read, re-read and interpret the Bible in the context of their lived experiences and realities. These are experiences and realities characterised by pain and suffering as a result of poverty and because of the socio-economic and political structures in which poverty is entrenched. This is also in the context in which poverty, inequality and unemployment are exacerbated by the COVID-19 pandemic. The prevalent corruption in the South African context is also not helping as it worsens poverty as resources meant for the poor are diverted from the poor.

In the context of the contemporary, supposedly liberated post-apartheid South Africa, the questions raised could be as follows: What does it mean to believe in the triune God when one continues to be black and impoverished? What does it mean when in a post-apartheid South Africa the majority of those who are poor are black? What does it mean to believe in God in the context in which they remain poor and continue to be deprived of essential services as a result of the depletion of state resources by some corrupt officials and public representatives? 
According to Berryman (1987:4), liberation theology is a systematic theology, a disciplined reflection on Christian faith and its implications. It is a reading, re-reading and an interpretation of Christian faith out of the experience of the poor and oppressed. It is an attempt to read the Bible and key Christian doctrines and the application thereof with the eyes of the poor and the oppressed. As the poor read, re-read and reinterpret Christian theology, they come to the same conclusion as Cone (1986), that:

[T] here can be no Christian theology that is not identified unreservedly with those who are humiliated and abused. In fact, theology ceases to be theology of the gospel if it fails to rise out of the community of the oppressed. (p. 1)

\section{Point of departure of liberation theology}

The point of departure of liberation theology is what liberation theologians refer to as 'the underside of history' (cf. Gibellini 1987:4; Gutierrez 1983). Liberation theology takes its point of departure in the reality of the misery described by the Catholic bishops at the Puebla meeting of the Latin American Episcopal Council (CELUM):

It is the most devastating and humiliating kind of scourge. And the situation finds expression in such things such as high rate of infant mortality, lack of adequate housing, health problems, starvation wages, unemployment and underemployment, malnutrition, job uncertainty, compulsory mass migrations, etc. [Puebla 29]

This is a description of the scandalous condition under which black people live, not in the 1960s but in the postapartheid South Africa, which has the most world acclaimed Constitution that promises a lot for all citizens of South Africa.

Liberation theology has a different starting point, which is the poor, the marginalised, that is, those about whom the rest of society could not care less (Brown 1978:60). It is with them that theology must start, and not with theories nor views from above but views from below (Brown 1978:61). It is in the life and situation of the poor where God is at work (Brown 1978:61). Put slightly different, with a different emphasis, Cone states that Jesus Christ the liberator, the helper and the healer of the wounded, is the point of departure for valid exegesis (hermeneutics) of the scriptures from a Christian perspective (Cone 1993:174). The fact which Cone emphasises is that the God of the Bible who is involved in history is the starting point. Cone (1993:174) goes on to state that any starting point that ignores God in Christ as the liberator of the poor and oppressed is ipso facto invalid. This starting point is dialectically related to Black cultural experience and black experience of pain and suffering. According to Cone (1993:174), this makes God and Christian theology social and political. According to Nolan, the point of departure is suffering. This is doing theology in contrast to thinking and theorising about theology. This is doing theology in a context of suffering.

\section{A different method, a different way}

Liberation theology understood itself as having a new method (hodos), a new way of doing theology. In the different method of liberation, which is no longer a new method, theology is rigorously understood as a second act which presupposes a first act, on which it reflects (Gibellini 1987:5; cf. Gutierrez 1999:29). The first act is the experience of faith and commitment to action. In this different way, the poor and oppressed are empowered to read, reread and interpret the Bible and their own faith in new way, in a different way. This happens in many black urban and rural communities such as townships of Soweto, Eldorado Park, Alexandra, Kagiso, Eersterust, Mangaung, Pella, Pitsi-di-sule-jang, and so on, without making headlines in the media.

It is that constitutes an epistemological break with the past and grants an epistemological privilege to the poor and oppressed. The poor are the interlocutors in Black Liberation Theology.

According to Gutierrez (1999:29), the distinction between the two moments (first act and second act) is a crucial point in the method of liberation theology. Others refer to the method as 'doing theology'. This is doing theology in contrast to thinking and theorising about theology. This is doing theology in a context of pain and suffering. According to Nolan, suffering is and should be the starting point of modern theology. He says:

[I]f one was to discern the new starting point for modern theology and spirituality in most of the Christian world today, one would have to say that it is suffering. (Nolan 1975:49)

This is a new way that Boesak refers to as a new way (then new way) of looking at the world we live in and the responsibility of the church in the world (Boesak 1977:2). Of course, it is a new theology that is no longer that new but different. This is the way that was followed in the process that led to the Kairos document of 1995 when pastors, theologians, and ordinary Christians came together to do theology instead of theorising about theology (cf. Dladla 1996; Kairos Southern Africa 2011).

\section{The significance of the Bible to the poor and the oppressed}

At face value, it may erroneously appear as if Black Theology has nothing to do with the Bible. This is particularly the case from the perspectives of the critics of Black Theology and all 'liberation theologies', that the Bible is not important to proponents of such theologies. On the contrary, the poor do read the Bible. The poor are a Bible-reading and Bible interpreting community. They do that in the context of their pain and suffering and in the context of poverty. In the South African context, the poor, the majority of whom are blacks do read the Bible in the light of their social experience. They do read, reread and interpret the Bible in their socio-culturaleconomic and political contexts. As they read, reread and interpret the Bible, according to Maimela (1990:191), they 
discover 'the contradictions between what the Bible proclaims and the message which their oppressors taught them'. Maimela (1990:191) goes on to correctly assert that the poor discovered the fact that the Bible was misused by the dominant whites to justify the enslavement and colonial domination of one racial group by another'. Writing in the context of Black Theology in apartheid South Africa, Maimela (1990) stated:

$[B]$ lack Theology seeks to interpret the oppressive conditions in which Blacks live in the light of the biblical message which proclaims that God's justice demands that the oppressed and the downtrodden be set free. (p. 191)

The Bible is a very central document to the poor. In their journeys of faith and in their struggle for liberation they read, reread and interpret the Bible in the light of their poverty and the associated socio-economic and political conditions under which they live.

The poor and the oppressed Christians and their pastors and theologians have an incredible and special relationship with the Bible and with the masses, as was illustrated in 1985, again in 1995 and later when they were involved in the development of the people's theology as articulated in the Kairos document (cf. Dladla 1995:2011; Kairos Southern Africa 1985, 2011). Just like the biblical community, the contemporary community of faith, especially the poor and oppressed, encounter the God of the Bible during all moments, particularly during moments of crises. They journey with the God of the Bible during moments of pain and suffering. As the result of their hope anchored in the God of the Bible, they remain hopeful that the liberating God will liberate them from poverty.

According to Mesters (1981:197), the Bible is important in the life and growth of grassroots communities. The Bible is important to the poor and the oppressed and liberation theologians and pastors, who are part of them as organic intellectuals, and who journey with them read, reread and interpret the Bible with them and not for them. The poor and the oppressed, together with their pastors and liberation theologians, grapple with the same biblical topics that all Christians grapple with. As the theologians and pastors read, re-read and interpret the Bible, they do that in the company of the poor and with the eyes of the poor. Liberation theologians are just facilitators as the poor and oppressed read and interpret their own faith in a new way, in a different way. That is the role they played during the time when the Kairos Movement produced the Kairos document in 1985 (Kairos Southern Africa 2011). As the poor proceed in their spiritual journeys, they experience the God of the Bible as the God who is fully involved in history. It is the God who reveals Godself in history in particular contexts.

\section{The true theology and the spiritual journey of the poor and the oppressed in the context of poverty}

Every true theology originates from a spirituality, that is, from a true meeting with God in history (Boff \& Boff 1987:3).
It is this spirituality that makes theology authentic, as Gutierrez correctly points out that 'an authentic theology is always a spiritual theology' (cf. Gutierrez 1999:29; cf. Gutierrez in Assmann 1975:15). According to Leonardo Boff, at the roots of the theology of liberation we find a spirituality, a mysticism, that is, the encounter of the poor with the Lord (in Boff \& Boff 1984:2). Boff goes on to point out that any theology that is not based on a spiritual experience is mere panting-religious breathlessness (Leonardo Boff in Boff \& Boff 1984:2). In the spiritual journeys of the poor and oppressed, they experience and encounter the biblical God, who is close to human beings. They experience God as a God of communion with and commitment to human beings (Gutierrez 1988:106). They experience the active presence of God in the company of the people, in line with the oldest and most enduring Biblical promises (Gutierrez 1988:106). In this experience God and Jesus are not experienced and encountered in the same distorted images that have been expressed from the white, Euro-American perspectives (cf. Cone 1997:vii). When the oppressed Christians, during the difficult period of the oppressive apartheid regime took it upon themselves to fight apartheid and its evil structures, they did that as part of their spiritual journey. Christians held hands with people from other religions and other organisations as they fought against injustices and the evils of apartheid. It cannot be different with Christians today. In their spiritual journey, they continue to fight against poverty and the socio-economic and political structures that are responsible for the prevalence of poverty.

This is consistent with Liberation theology and its various brands and in all continents which was born when faith confronted the injustices done to the poor (Boff \& Boff 1987:3). Faith is of cardinal importance in all theology and black liberation theology is no exception. The act of faith in people's spiritual journeys is at the root of all theology (Gutierrez in Assmann 1975:14).

\section{Who are the poor?}

Boff and Boff states that by 'the poor' we do not really mean the individual who knocks on the door asking for alms. We mean a collective poor, the 'popular classes', a category which is a much wider category than the proletariat singled out by Karl Marx (Boff \& Boff 1987:3). The poor are the workers who are exploited by the capitalist system; the underemployed, those pushed aside by the production process - a reserve army always at hand to take the place of the employed. They are the labourers of the countryside, and migrant workers with only seasonal work (Boff \& Boff 1987:4). Gutierrez includes the following as those who are part of the poor: the dominated peoples, exploited social classes, despised races and marginalised cultures (Gutierrez 1996:23; cf. Gutierrez 1988:xxi). According to Gutierrez (1996:23), they constitute a de facto social collectivity who live in a situation of inhuman misery and anti-evangelical poverty. These are those who are regarded as 'the nonpersons', that is, those who are not recognised as people by the existing social order (Gutierrez 1999:28). They are the 
socially and historically oppressed who makes up the poor as a social phenomenon (Boff \& Boff 1987:4). The poor are a whole class of the marginalised and exploited persons in our society, marked as the society, by an exclusive partnership with a dependent capitalism (Leonardo Boff in Boff \& Boff 1984:2). The poor are those that liberation theologians refer to as the crucified people of God. These are the crucified that Boff and Boff (1987:4) say as those who must be raised to life. According to Gutierrez, the poor are those who occupy a central position in the reflection that we call the theology of liberation (Gutierrez 1996:22). The inhuman misery or the anti-evangelical poverty in which the poor live is characterised by shortage of food, shortage of housing, inadequate health services, inadequate educational facilities and services, the exploitation of labour, chronic unemployment, disrespect for human worth and dignity, unjust restrictions on freedom of expression and the daily plight of the poor (Gutierrez 1996:23). All these characterise the plight of the poor and oppressed in the South African context in which there are the usual socio-economic and political structures that entrench poverty. An additional dimension in recent years is corruption that erodes billions of rands that could have been utilised to improve the living conditions of the poor. As a result of these social structures and corruption, the poor are subjected to death, that is, premature death. They are subjected to institutional violence (Gutierrez 1996:23; cf. Gutierrez 1988:xxi). The conditions to which the poor are subjected are degrading and scandalous and inimical to human dignity and contrary to the will of God (Gutierrez 1988:165). The poor are not poor by accident or poor because they are lazy. They do not exist as an act of destiny (Gutierrez in Assmann 1975:7). They are a by-product of the system in which we live and for which human beings are responsible (cf. Gutierrez in Assmann 1975:7). This is the case with blacks who were previously disadvantaged and are still disadvantaged in a democratic, non-racial and supposedly non-sexist South Africa, where women and girls are subjected to gender-based violence and abuse.

\section{The preferential option for the poor}

The controversial phrase 'the preferential option of the poor' was first used in the context of liberation theology in the closing document of the conference of the Latin American episcopate at Puebla which states: 'We affirm the need for conversion on the part of the whole church to a preferential option for the poor, an option aimed at their integral liberation' (Gibellini 1987:4; cf. Berryman 1987:43, 44).

The Boff brothers, Leonardo and Clovodis support this preferential option of the poor when they point out:

[W]e are on the side of the poor only when we struggle alongside them against the poverty that has been unjustly created and forced on them. Service in solidarity with the oppressed also implies an act of love for the suffering Christ, a liturgy pleasing to God. (Boff \& Boff 1987:4)

As he advocates for taking sides with the poor and oppressed, Brown (1978:175) correctly points out to the truth that we take sides all the time. Claiming not to take sides is effectively taking sides, consciously or unconsciously. The temptation is always to be on the wrong side. For instance, 'lack of political involvement is actually a political support for the status quo' (Brown 1978:175).

The poor and the oppressed have agency and they are not only mere passive recipients of good actions and charity from others. If charity is offered, it should only be as an emergency measure, with a determination to partner with the poor themselves in actions geared towards socioeconomic and political transformation.

In concurrence with the God who takes sides with those who are weak, the poor and the oppressed, Cone (1997:ix) challenges theologians and preachers of the Christian church to 'make it unquestionably clear that the God of Moses and of Jesus makes an unqualified solidarity with the victims, empowering them to fight against injustice'.

Just as much as the plight of oppressed slaves in the Exodus were at the heart of God's actions, the poor, the oppressed and the marginalised are at the heart of Jesus' preaching of the Reign of God (Lk. 4:16-20). In line with this, Gutierrez correctly points out that a 'preferential commitment to the poor and oppressed is at the very heart of Jesus' preaching of the Reign of God' (Gutierrez 1996:22). Put slightly differently, Cone (1997:vii) identifies liberation as the heart of the Christian gospel, with blackness being the mode of God's presence. The term preference precludes exclusivity according to Gutierrez (1996:26). It simply points to who ought to be the first, and not the only one, that is the first object of our solidarity (Gutierrez 1996:26).

This formula of 'preferential option for the poor' is biblical. It means an option for God of the Reign as proclaimed to us by Jesus. The whole Bible, from the story of Cain and Abel onwards, is marked by God's love and predilection for the weak and the abused of human history (Gutierrez 1996:27). This is what Gutierrez (1996:27) refers to as a theocentric and prophetic option.

According to Gutierrez, the opportunity for the poor and the oppressed through a liberating commitment leads to the realisation that this commitment cannot be isolated from the social set-up to which they belong. Otherwise, we would not go beyond 'being sorry for the situation' (Gutierrez in Assmann 1975:7). When people are impoverished, oppressed and impoverished to the extent that they are dehumanised, the word 'sorry' does not help. What is required is prophetic activism which is aimed at transforming society. Therefore, to opt for the poor is to opt for the marginalised and the exploited, to take stock of the social conflict and to side with the dispossessed (Gutierrez in Assmann 1975:8).

\section{Liberative hermeneutics}

Hermeneutics in general is the science and technique of interpretation by means of which we are enabled to 
understand the original meaning of any writings (or realities) which are no longer immediately comprehensible to men and women (Leonardo Boff in Boff \& Boff 1984:8-9). Hermeneutics interprets the Christian scriptures and more importantly documents preserved in the church tradition (Leonardo Boff in Boff \& Boff 1984:9). Between us and the Bible, more than 2000 years intervene (Leonardo Boff in Boff \& Boff 1984:9). Hermeneutics builds a bridge and for that reason it is referred to as a hermeneutic mediation (Leonardo Boff in Boff \& Boff 1984:9). Gibellini (1987:10) also weighs in on the fact that liberation theology calls for a renewed use of hermeneutical mediation. He goes on to point out that liberation theology does not interpret scripture and the sources of the Christian tradition in the abstract, but on the basis of a specific social situation, read through socioanalytical mediation (Gibellini 1987:10).

In the context of liberation theology, what is read, re-read and interpreted is not only the scriptures, but the reality as experienced by the poor. It is not only what happened in the past, but also what is happening in the contemporary context that is marked by poverty, COVID-19 and vaccine nationalism by the rich nations. In their spiritual journeys, the poor and oppressed are always at a point where they encounter one another, at what Roberts (1993:184) refer to as the hermeneutical nexus. That is also the point at which biblical theology and black theology enter and begin their dialogue (Roberts 1993:184). This resonates with the hermeneutics of Black theology which embraces the hermeneutical principle appreciated and used by the poor and oppressed. This is in line with what is described by Cone (1993) as:

$[T]$ he hermeneutical principle for an exegesis of the scriptures is the revelation of God in Christ as the liberator of the oppressed from social oppression and to political struggle, wherein the poor recognize that their fight against poverty and injustice is not only consistent with the gospel but is the gospel of Jesus Christ. (p. 174; cf. Bennett 1993:177)

\section{Poverty and COVID-19 and vaccine nationalism in the South African context}

South Africa has been struggling with the three challenges that stubbornly refuse to disappear, namely poverty, inequality and unemployment for a long timenotwithstanding many years since liberation in 1994. The latest dimension that complicates life for the poor is corruption, which robs the poor of the much-needed resources for basic services, infrastructural development, job creation and economic growth and justice. The political power that is in the hands of mainly blacks has not yet translated into economic transformation that liberates South Africans from poverty and the associated inequality and unemployment. These challenges are exacerbated by COVID-19, a pandemic which has turned the whole world upside down. This pandemic arrived on the global scene in Wuhan, China in December 2019 and was declared a pandemic on 11 March 2020 as the virus began to spread throughout the whole world. In South
Africa, the first reported case was on 5 March 2020 and soon thereafter South Africa became the African country with the highest number of cases of infection and cases of death. On 26 March 2020, South Africa entered the 'hard lockdown' (level5) for an initial period of 21 days, followed by extensions and variations of lockdown stages, with stage 0 still remote by 03 June 2021 (cf. Ranchhod \& Daniels 2020:4). This global pandemic became a health crisis that according to Ranchhod and Daniels exacerbated the ever-worsening crisis of unemployment (Ranchhod \& Daniels 2020:1). This goes hand in hand with poverty and inequality. The most vulnerable and severely affected groups are women, African (Blacks), youth and less educated groups (cf. Ranchhod \& Daniels 2020:3). While the negative impact of COVID-19 is felt throughout the whole world, the adverse consequences are more severely felt in developing countries, which are often referred to as emerging markets. According to Jain et al. (2020:1) 'it is widely expected that the poverty impact of Covid-19 will be most severe in emerging market economies'. Poor countries do not yet have capacities to manufacture vaccines, unlike the wealthy countries such as the Unites States of America, the United Kingdom, China and others. The wealthy countries are way ahead in terms of manufacturing, acquisition of vaccines and vaccination of their populations. In fact, they do hoard millions of vaccines while poor countries are struggling to access vaccines. This is the result of vaccine nationalism that leaves out citizens of poor counties. According to Hassoun, rich countries such as the USA and the UK have long started to vaccinate their populations against COVID-19, whereas poor countries are likely to have no access to vaccines for years (Hassoun 2020). Vaccine nationalism is not uncommon among rich nations. Hassoun assert that vaccine nationalism fails to respect basic human rights and the people who have the rights (Hassoun 2020). Hassoun (2020) reiterates the argument that rich countries have contributed to the global poverty through a shared and violent history of colonialism and oppression. The severity of the impact is not only at the global level but at the local and individual levels where the poor and oppressed are subjected to poverty and associated socio-economic and political ills. In the South African context, the poor are living in overcrowded informal settlements, peri-urban areas, and rural villages where it is difficult to adhere to nonpharmaceutical measures such as social distancing, washing of hands or sanitising regularly. They do not have access to adequate health services, adequate infrastructure, and other basic amenities. It is under these circumstances, that most impoverished blacks do their theological reflections as they read, re-read and interpret the Bible from liberative hermeneutics.

\section{Conclusion}

The main argument of this article is that the Bible is particularly important to the poor in their journeys of faith. As they read, re-read and interpret the Bible, they do that from a liberative hermeneutics perspective. They find inspiration in the Bible stories and biblical themes about God, 
whom they appreciate and understand as a liberating God and God of justice who is involved in human history. They appreciate God as the God who takes sides with the poor and the oppressed. In the South African context, the majority of those who are poor are black and they are found mainly in informal settlements, townships and rural villages and they continue to exist as the Bible-reading communities amidst their pain and suffering. They do this in the context of poverty and its associated socio-economic and political realities and experiences. They read, reread and interpret the Bible in the context of COVID-19, which is exacerbating poverty, inequality and unemployment. In their spiritual journeys, the poor encounter God and encounter each other at a hermeneutical nexus and at a point where Biblical Theology meets Black Theology, which is a critical reflection of the gospel in the light of their lived experiences and realities under exceedingly difficult circumstances characterised by poverty, COVID-19, difficulties in accessing vaccines and vaccine nationalism as perpetrated by the rich and powerful countries. The article attempted to contribute to the efforts to correct the misconception that liberation theologies, including Black Theology, have nothing to do with the Bible and with biblical theology. The article emphasises the centrality of the Bible in the spiritual journeys of the poor as they liberate themselves, with pastors and theologians merely serving as organic intellectuals who are articulating the people's theologies and who recognise that the poor have agency.

\section{Acknowledgements Competing interests}

The author declares that he has no financial or personal relationships that may have inappropriately influenced him in writing this article.

\section{Author's contributions}

O.A.B. is the sole author of this article.

\section{Ethical considerations}

This article followed all ethical standards for research without direct contact with human or animal subjects.

\section{Funding information}

This research received no specific grant from any funding agency in the public, commercial or not-for-profit sectors.

\section{Data availability}

Data sharing is not applicable to this article as no new data were created or analysed in this study.

\section{Disclaimer}

The views and opinions expressed in this article are those of the author and do not necessarily reflect the official policy or position of any affiliated agency of the author.

\section{References}

Bennett, R.A., 1993, 'Biblical theology and black theology', in J. Cone \& G.S. Wilmore (eds.), Black theology: A documentary History volume one: 1986-1979, 2nd edn., Revised, pp. 177-192, Orbis Books, Maryknoll, New York, NY.

Berryman, P., 1987, Liberation theology: The essential facts about the revolutionary movement in Latin America and beyond, Pantheon Books, New York, NY.

Boff, L. \& Boff, C., 1984, Salvation and liberation: In search of balance between politics and faith, Orbis Books, Maryknoll, New York, NY.

Boff, L. \& Boff, C., 1987, Introducing liberation theology, Burns and Oates, Kent.

Boshoff, C.W.H., Smith, P.E.S. \& Crafford, S.D., 1972, Swart Teologie, N.G. Kerk Boekhandel, Pretoria.

Brown, R.M., 1978, Theology in a new key: Responding to liberation theology, The Westminster Press, Philadelphia, PA.

Buffel, O.A., 2010, 'Black theology and the Black masses: The need for an organic relationship between black theology and the black masses', Scriptura $105,470-480$

Bundy, C., 2014, Short-changed? South Africa since apartheid, Jacana, Auckland Park.

Chikane, F., 1996, 'The state of the nation: From Kairos to ... jubilee', in T. Dladla (ed.), Kairos 95: At the threshold of jubilee, Institute for Contextual Theology, Johannesburg.

Chisholm, L., 2017, Between worlds: German Missionaries and the transition from mission to Bantu education in South Africa, Wits University Press, Johannesburg.

Cone, J., 1986, A black theology of liberation, 2nd edn., Orbis Books, Maryknoll, New York, NY.

Cone, J., 1993, 'Biblical revelation and social existence', in J. Cone \& G.S. Wilmore (eds.), Black theology: A documentary history volume one: 1986-1979, 2nd edn., Revised, pp. 159-176, Orbis Books, Maryknoll, New York, NY

Cone, J., 1997, Black theology and black power, Orbis Books, Maryknoll, New York, NY.

Dladla, T., 1996, Threshold to Jubilee. Conference Report, Institute for Contextual Theology, Johannesburg.

Farisani, E.B., 2014, 'Interpreting the Bible in the context of apartheid and beyond: An African perspective', Studia Historiae Ecclesiasticae 40(2), 207-225.

Gibellini, R., 1987, The liberation theology debate, SCM Press, London.

Gutierrez, G., 1975, 'Introduction: Liberation, theology and proclamation', in H. Assmann (ed.), Practical theology of liberation, Search Press, London.

Gutierrez, G., 1983, The power of the poor in history, SCM Press, London.

Gutierrez, G., 1988, A theology of liberation, Orbis Books, Maryknoll, New York, NY.

Gutierrez, G., 1996, 'Option for the poor', in J. Sobrino \& I. Ellacuro (eds.), Systematic theology: Perspectives from liberation theology, pp. 22-37, Orbis Books, Maryknoll, New York, NY.

Gutierrez, G., 1999, 'The task and content of liberation theology', in C. Rowland (ed.), The Cambridge companion to liberation theology, Cambridge University Press, Cambridge.

Hassoun, N., 2020, 'Response against vaccine nationalism', Journal of Medical Ethics https://doi.org/10.1136/medethics-2020-107193

Jain, R., Budlender, J., Zizzamia, R. \& Bassier, I., 2020, The labour market and poverty impacts of covid-19 in South Africa, Southern Africa Labour and Development Research Unit, UCT, Cape Town.

Kairos Southern Africa, 2011, The South Africa Kairos document 1985, viewed n.d., from https://kairossouthernafrica.wordpress.com/2011/05/08/the-south-africakairos-document-1985/.

Maimela, S.S., 1990, Modern trends in theology, Skotaville Publishers, Braamfontein.

Mosala, I.J., 1989, Biblical hermeneutics and black theology in South Africa, Wm. B. Eerdmans Publishing Co., Grand Rapids, MI.

Nolan, A., 1975, God in South Africa: The challenge of the gospel, David Phillips, Cape Town.

Nyapokoto, R., 2014, 'The road between Sandton and Alexandra Township: A Fanonian approach to the study of poverty and privilege in South Africa', unpublished M.A. dissertation, UNISA.

Ranchhod, V. \& Daniels, R.C., 2020, Labour market dynamics in South Africa in the time of Covid-19: Evidence from wave 1 of NIDS-CRAM survey, Working Paper Series, No 265, Version 1, pp. 1-24, Southern Africa Labour and Development Research Unit, UCT, Cape Town.

Rule, S. \& Mcwango, B., 2010, 'Christianity in South Africa: Theory and practice', in B. Roberts, M. Kivilu \& Y.D. Davids (eds.), South African social attitudes 2 nd report: Reflections on the age of hope, pp. 185-197, HSRC Press, Cape Town.

Tutu, D.M., 1993, 'Black theology/African theology-soul mates or antagonists', in J.H. Cone \& G.S. Wilmore (eds.), Black theology: A documentary history volume 1: 1966-1979, Orbis Books, Maryknoll, New York, NY.

West, G., 2015, 'Reading the Bible with the marginalised: The value/s of contextual Bible reading', Stellenbosch Theological Journal 1(2), 235-261. https://doi. org/10.17570/stj.2025.v1n2.all

World Bank, 2020, Poverty and equity brief: Sub-Saharan Africa-South Africa, April 2020 viewed 01 August 2021, from https://databank.worldbank.org/data/download/ poverty/33EF03BB-9722-4AE2-ABC7-AA2972D68AFE/Global_POVEQ_ZA. 